\title{
An early record of the genus Cytheridella Daday, 1905 (Ostracoda, Limnocytheridae, Timiriaseviinae) from the Upper Cretaceous of Mali, West Africa: palaeobiogeographical and palaeoecological considerations
}

\author{
JEAN-PAUL COLIN ${ }^{1}$, YVETTE TAMBAREAU ${ }^{2}$ \& VALERY A. KRASHENINNIKOV ${ }^{3}$ \\ ${ }^{1}$ Esso Rep, 213 Cours Victor Hugo 33323, Bègles cedex, France. \\ ${ }^{2}$ Laboratoire de Géologie Structurale, Université Paul Sabatier, 38 rue des Trente-six Ponts 31400 Toulouse, France. \\ ${ }^{3}$ Institute of Geology, Academy of Sciences 7 Pyzevskiy Per., 109017 Moscow, Russia.
}

\begin{abstract}
The limnic ostracod genus Cytheridella Daday, 1905 (Limnocytheridae, Timiriaseviinae), previously only known from Plio--Pleistocene sediments and Recent lacustrine environments of South and Central America, the Caribbean Islands, Florida and Equatorial Africa, and from earliest Eocene to Early Oligocene Eurasian localities, is found for the first time in the Upper Cretaceous (undifferentiated Campanian-Early Maastrichtian) of northern Mali, West Africa, suggesting an African origin for the genus. The association with the brackish-water ostracod genus Sarlatina suggests a mixo- or oligohaline environment for the Cretaceous species of Cytheridella. J. Micropalaeontol. 16(1): 91-95, May 1997.
\end{abstract}

\section{INTRODUCTION}

The limnic ostracod genus Cytheridella Daday, 1905 (Cytheracea, Limnocytheridae, Timiriaseviinae, Cytheridellini) is represented by several Plio-Pleistocene and Recent species geographically restricted to South and Central America, the Caribbean Islands, Florida and Equatorial Africa (Pinto \& Sanguinetti, 1962; McKenzie, 1971; Purper, 1974; Colin \& Danielopol, 1980; Martens \& Behen, 1997). In Australia, Cytheridella is replaced by the genus Gomphodella De Deckker, 1981 which is morphologically very close.

Until recently, pre Plio-Pleistocene representatives of this genus were known only from few Eurasian localities of earliest Eocene to Early Oligocene age (Fig. 1):
- Earliest Eocene (Ilerdian) of southern France, Montagne Noire: Cytheridella audensis Tambareau et al., 1991 (=Cytheridella $\mathrm{n}$. sp. in Tambareau et al., 1989);

- Early Eocene of India (Ypresian?): Cytheridella strangulata (Jones, 1905) and Cytheridella gujratensis Bhandari, 1993 (nomen nudum) (=Cytheridella sp. in Bhandari et al., 1991);

- Middle Eocene (Lutetian) of southern France, Fontaine de Grabels near Montpellier: Cytheridella sp. (Y. Tambareau collection, unpublished);

- Late Eocene (Bartonian) of Hungary: Cytheridella gantensis Monostori, 1977;

- Eocene of Slovenia: Cytheridella buseri Monostori, 1993;

- Early Oligocene (Melanienton) of northen Germany: Cytheridella ritzkowskiana Carbonnel \& Ritzkowski, 1969.

\begin{tabular}{|c|c|c|c|c|}
\hline & $\begin{array}{c}\text { South and Central } \\
\text { America }\end{array}$ & Africa & Europe & India \\
\hline Recent & $\begin{array}{c}\text { C. ilosvayi, C. alosa } \\
\text { C. argentinensis } \\
\text { C. boldii } \\
\end{array}$ & $\begin{array}{l}\text { C. monodi } \\
\text { C. chariessa } \\
\text { C. damasi } \\
\end{array}$ & & \\
\hline Plio-Pleistocene & $\begin{array}{c}\text { C. boldii } \\
\text { C. danielopoli } \\
\text { C. postornata } \\
\end{array}$ & & & \\
\hline \multicolumn{5}{|l|}{ Miocene } \\
\hline \multicolumn{5}{|c|}{ C. ritzkowskiana } \\
\hline Eocene & & PGomphocythere L234 & $\begin{array}{l}\text { C. gantensis } \\
\text { C. buseri } \\
\text { C. audensis }\end{array}$ & $\begin{array}{l}\text { C. strangulata } \\
\text { "C. gujratensis" }\end{array}$ \\
\hline \multicolumn{5}{|l|}{ Paieocene } \\
\hline $\begin{array}{c}\text { Campanian- } \\
\text { Maastrichtian }\end{array}$ & & Cytheridella sp. & & \\
\hline
\end{tabular}

Fig. 1. Stratigraphical and geographical distribution of fossil and recent species of Cytheridella. 
Other fossil species assigned to the genus Cytheridella by various authors have been removed from it by Purper (1974: pp. 655-656). The oldest species previously included in this genus, Cytheridella? barnstorfensis Martin, 1957 (in Martin \& Weiler, 1957), from the Late Jurassic of Germany, has been recently reattributed to the genus Marslatourella (Marslatourella?) Malz, by Schudack (1994). It is also possible that ?Gomphocythere sp. L 234 Grékoff, 1958 from the Tertiary (Eocene, 'Grès Polymorphes') of Central Zaire, lacking the lateral ventral ridge on both valves typical of most species of the genus Gomphocythere Sars, 1924 , belongs to the genus $C y$ theridella, as already suggested by Pinto \& Sanguinetti (1962).

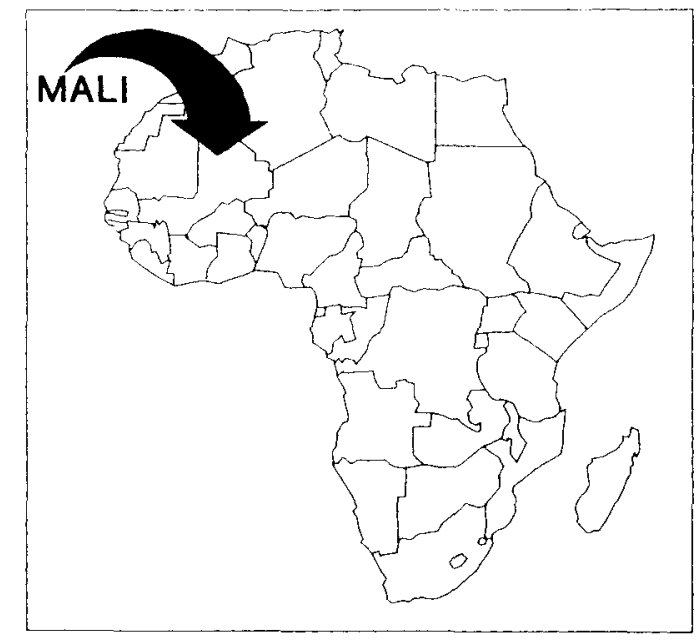

Fig. 2. Location map of the studied area (Mali).

\section{THE GENUS CYTHERIDELLA IN THE UPPER CRETAC- EOUS OF MALI \\ Stratigraphic framework}

Recent study of material from northern Mali, West Africa (Fig. 2), led to the discovery of rare specimens of a new species of Cytheridella in sediments of Upper Cretaceous age (Colin et al., 1996). The level which has yielded this species, in the borehole. In Talack, contains also the ostracod genera Virgatocypris, Zonocypris, Cypria, Darwinula and Sarlatina, as well as charophyte oogonia of Platychara caudata Grambast and Porochara globosa Grambast. It is located below the first welldated Late Maastrichtian marine beds (previously dated as Danian by Berggren, 1974) containing the foraminifera Laffiteina bibensis Marie and the ammonite Lybicoceras ismaeli Zittel (Krasheninnikov \& Trofimov, 1969). According to Bellion et al. (1990), the age of this horizon is not very clear but is probably Campanian to Early Maastrichtian on the basis of molluscs faunas. Charophyte oogonia suggest a Campanian age, although a Maastrichtian age cannot be discounted (M. Feist, pers. comm.)

\section{Taxonomic comments}

Subclass Ostracoda Latreille, 1806

Order Podocopida G. W. Müller, 1894

Suborder Podocopa Sars, 1866

Superfamily Cytheracea Baird, 1850

Family Limnocytheridae Klie, 1938

Subfamily Timiriaseviinae Mandelstam, 1960

Tribe Cytheridellini Danielopol \& Martens, 1989 emend Martens, 1993

Genus Cytheridella Daday, 1905

(= Onychocythere Tressler, 1939) Cytheridella $\mathrm{sp}$.

(Fig. 3)

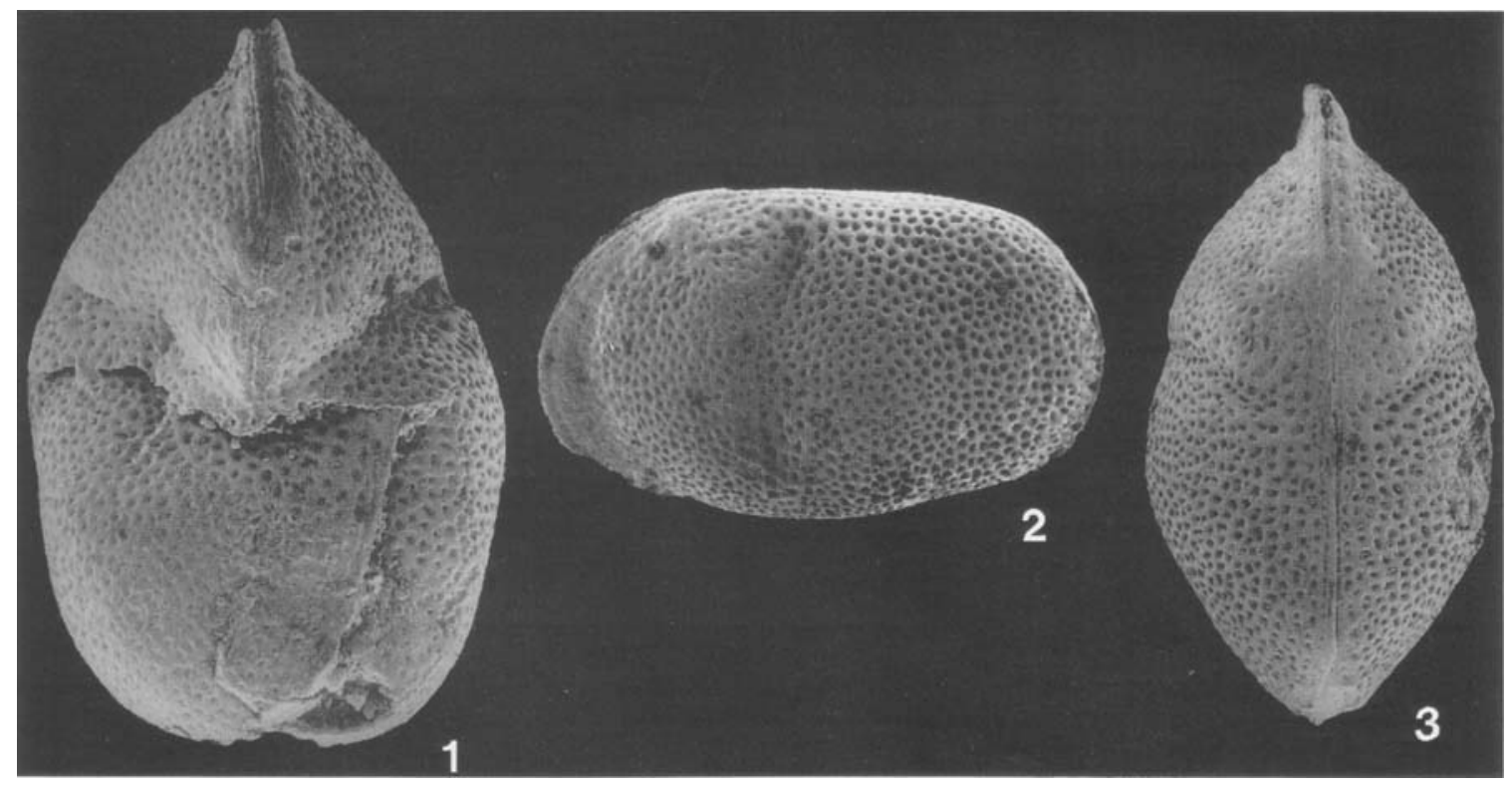

Fig. 3. Cytheridella sp., borehole In Talack, Mali, sample N2. (1) Female, dorsal view; (2) male left lateral view; (3) male dorsal view. All figures $\times 80$. 
Remarks. In 1978, Colin \& Danielopol separated the genus Cytheridella from the Timiriaseviinae and included it in the subfamily Limnocytherinae. In 1989, Danielopol \& Martens (in Danielopol et al., 1989) erected the tribe Cytheridellini including the genera Cytheridella, Gomphocythere and Gomphodella. Recently, Martens (1993) emended the Cytheridellini diagnosis. According to K. Martens (pers. comm.) the tribe Cytheridellini belongs to the Timiriaseviinae and not to the Limnocytherinae. Diagnosis. The Malian Upper Cretaceous species has a typical Cytheridella external morphology characterized by:

- a deep and narrow dorso-median vertical sulcus extending about two-thirds of the way down the valves;

- a broad, smooth and compressed anterior margin;

- an ornamentation formed by numerous small and deep polygonal pits;

- a very pronounced sexual dimorphism with the females developing a distinct brooding cavity.

Unfortunately, since only closed carapaces were found, the internal characters could not be observed.

Affinities and differences. By its outline, this species is closer to the Recent south American type-species Cytheridella ilosvayi Daday, 1905 (=: Cytheridella ometepensis Swain \& Gilby, 1965), and to Plio-Pleistocene species from the Upper Amazon Basin of Brazil and Colombia Cytheridella danielopoli Purper and Cytheridella postornata Sheppard \& Bate, than to the Eocene species of Hungary and Slovenia, respectively Cytheridella gantensis Monostori and Cytheridella buseri Monostori which are more elongate. Besides minor details of the outline, the Malian Upper Cretaceous species differs from other known species of the genus by its strong ornamentation formed by numerous small and deep polygonal pits.

\section{Dimensions.}

$L=0.73 \mathrm{~mm}$ (female) $-0.92 \mathrm{~mm}$ (male)

$h=0.43 \mathrm{~mm}$ (male)

$w=0.62 \mathrm{~mm}$ (female) $-0.40 \mathrm{~mm}$ (male)

\section{Palaeoenvironmental considerations}

According to Purper (1974) all the recent species of Cytheridella live in fresh-water (maximum salinity $2.5 \%$ ), permanent (eggs cannot withstand desiccation, as with all members of the Cytheridellini - Martens, 1993), warm (temperature between 16 and $30^{\circ} \mathrm{C}$ ), shallow limnic environments with well developed aquatic vegetation. They are always observed in association with other freshwater genera such as Candona, Darwinula, Eucypris, Cypris, Candonopsis, Gomphocythere, Potamocypris, Chlamydotheca... For Keyser (1977), Cytheridella alosa (Tressler, 1939), which according to Purper (1974) is a junior synonym of Cytheridella ilosvayi Daday, 1905, observed in Florida is a 'true limnic species which, however, is often washed into the oligohaline zone' where it occurs with Cyprideis.

In Australia, the closely related genus Gomphodella is considered to be a 'freshwater species which can withstand a slight amount of dissolved solid in water, with its highest salinity recorded at 2.3\%o' (De Deckker, 1981). The other related African genus Gomphocythere can also occur in slightly saline conditions (K. Martens, pers. comm.) and highly alkaline waters, up to $>30 \mathrm{meq}^{-1}$ (Cohen et al., 1983).

Fossil species are also often found in strictly freshwater environments, as in the Middle Eocene of Grabels near Montpellier (southern France), where Cytheridella is associated with Frambocythere and mammals. However, in several cases, Cytheridella is known to occur in mixohaline environments:

- Pleistocene and Holocene of Argentina (Zabert \& Herbst, 1986; Bertels \& Martinez, 1990), in which Cytheridella ilosvayi and Cytheridella aff. ilosvayi occur with truly limnic ostracods and the brackish-water species Cyprideis salebrosa van den Bold.

- Sub-recent and Pleistocene of Venezuela and Plio-Pleistocene of the Dominican Republic and Trinidad (van den Bold, 1971, 1986), in which Cytheridella boldii Purper, 1974 is found with the brackish-water genus Cyprideis. For these levels van den Bold (1971, p. 459) suggests a rather high alkalinity.

- Plio-Pleistocene from the Upper Amazon Basin, Colombia and Brazil (Pebas Fm.), in which Cytheridella danielopoli Purper, 1979 (=Cytheridella sp. A Purper, 1977) and Cytheridella postornata Sheppard \& Bate, 1980, are found either in monospecific assemblages or with the brackish-water genera Cyprideis, Proparacytheridea, Perissocytheridea and the truly marine genera Pacambocythere and Rhadinocytherura.

- Eocene of Hungary in which Cytheridella gantensis is associated with lagoonal molluscs and dasycladacean algae (Monostori, 1977, 1993).

- Early Eocene of India in which Cytheridella gujratensis is found with the brackish-water genus Neocyprideis and rare arenaceous foraminifera (Bhandari, 1993).

- Earliest Eocene (llerdian) of southern France in which Cytheridella audensis occuring with the limnic ostracod Frambocythere, Cypris, Candona and Virgatocypris can also be associated with the brackish-water genus Neocyprideis (Tambareau et al., 1991).

In Mali, although typical freshwater genera occur in the assemblage (Virgatocypris, Cypria, Darwinula and Zonocypris), a lagoonal oligohaline environment is suggested by the presence in the sample of a great number of the cytherid genus Sarlatina wich represents more than $50 \%$ of the fauna (Fig. 4), and whose ecological requirement was probably very close to that of Cyprideis (Babinot \& Colin, 1976).

Whether Cytheridella actually lived in the lagoonal environ-

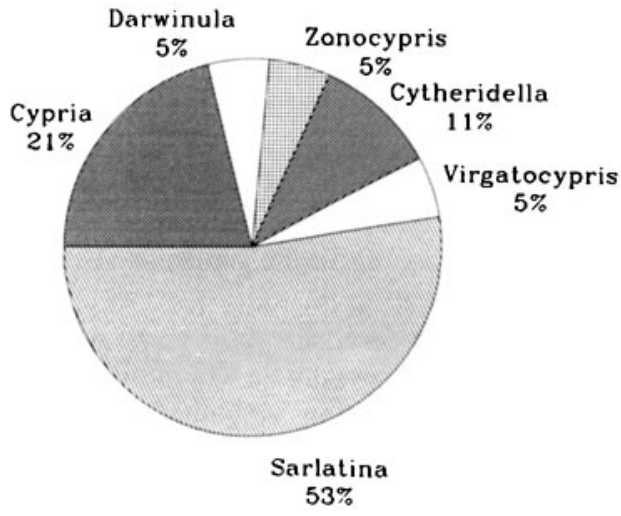

Fig. 4. Qualitative and quantitative composition of the level with Cytheridella in the borehole In Talack. 
ment or was transported into it, as suggested by Monostori (1993) for the Eocene of Hungary and by Keyser (1977) for recent environments of southern Florida, cannot be proved. However, the fact that in Mali the specimens found are closed carapaces does not favour a transportation hypothesis. The high percentage of closed carapaces observed in Gomphodella maia De Deckker, 1981 in sub-Recent sediments of Tasmania, southern Australia, has been explained (De Deckker, 1981, 1982) by the supposition that this species could burrow in the sediment to withstand short periods of desiccation.

Concerning Cytheridella postornata from the Plio-Pleistocene of Colombia, Sheppard \& Bate (1980) argue that 'Although a large species, the shell is thin and delicate and no extensive transport of the material is envisaged'.

Similar problems concerning the salinity tolerance and transportation into marine environments of the Mesozoic related genera Timiriasevia and Theriosynoecum have been discussed by various authours (see synthesis in Carbonel et al., 1988, pp. 443-447).

In conclusion it can be said that Recent species of Cytheridella are present in various types of permanent limnic environments, from truely lacustrine (Cytheridella chariessa Rome, 1977 (in Rome \& De Deckker, 1977) in Lake Kivu in Zaire), to marginal environments (for example Cytheridella alosa in Florida (Keyser, 1977)). It is assumed that fossil species had the same ecological requirements.

\section{Palaeobiogeographical considerations (Fig. 5)}

This species of Cytheridella of Campanian-Early Maastrichtian age is the oldest known representative of the genus, the previously known oldest species being of earliest Eocene age (Cytheridella audensis Tambareau et al., 1991). Its presence in Mali during this period suggests that the genus, like other members of the Timiriaseviinae such as Frambocythere, recently reported from the Albian of Zaire (Colin, 1993), probably originated in Africa during the Cretaceous.

During the Early Tertiary (earliest Eocene to Early Oligocene), it spread over Europe and India from which it subsequently disappeared, probably as the result of climatic deterioration (cooling). In fact, the major change in lacustrine ostracod fauna and the appearance of Cytheridella in southern France occur during the Middle llerdian (earliest Eocene) and is associated with a marked climatic warming event well documented by subtropical to tropical floras (Tambareau et al., 1991).

Until now, despite a great number of studies, no Miocene representative of the genus has been reported. The only Miocene species formerly assigned to Cytheridella, Cytheridella mediterranea Zalanyi, 1913 from the Miocene of Hungary, being coarsely reticulate and lacking the distinctive vertical sulcus, certainly does not belong to the genus, as already suggested by Purper (1974).

In the Plio-Pleistocene, the genus is only known from few South American localities (Brazil, Colombia and Venezuela) and its present day distribution is limited to Equatorial Africa (Cameroon and Zaire), South America (Argentina, Paraguay, Brazil, Venezuela and Chile), Central America (Nicaragua), the Caribbean Islands (Dominican Republic, Cuba and Trinidad) and the southern United States (Florida). The absence of

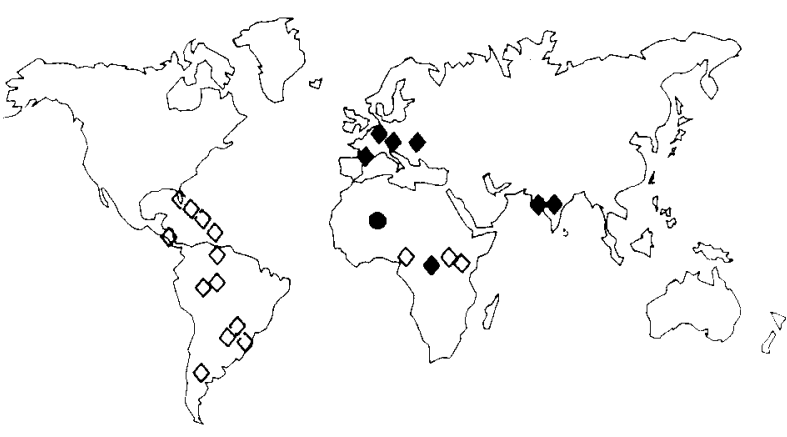

$\checkmark$ Plio-pleistocenefRecent

- Eocene-Oligocene

Upper Cretaceou

Fig. 5. Geographical distribution of fossil and recent species of Cytheridella.

Cytheridella from pre-Plio-Pleistocene sediments in South and Central America is most likely due to the lack of studies.

Other recent members of the Cytheridellini are geographically restricted to South and East Africa (Ethiopian Realm) and Israel for Gomphocythere (Martens, 1993), and Australia for Gomphodella (De Deckker, 1981)

\section{CONCLUSION}

The early occurrence of the limnic ostracod genus Cytheridella in the Campanian-Early Maastrichtian of Mali, suggests that this genus, which had a strictly Eurasian distribution during the Eocene-Oligocene and since the Plio-Pleistocene has been geographically restricted to South and Central America, the Caribbean Islands, Florida and Equatorial Africa, probably originated in West Africa during the Late Cretaceous. The association with other freshwater ostracods and the brackishwater genus Sarlatina supports a mixo- or oligohaline environment for the Cretaceous species.

\section{ACKNOWLEDGEMENTS}

We are pleased to thank Prof. L. Hottinger (Basle, Switzerland) for suggesting this study and his judicious comments, $\mathrm{Dr} \mathrm{K}$. Martens (Brussels, Belgium) for having thoroughly reviewed our work, Dr A. Bhandari (Dheradun, India) who sent us photographs of her Indian material, all the participants of the Working Group 'Evolution des Timiriaseviinae' for stimulating discussions, especially Dr P. Carbonel (Talence, France) and Dr. D. Danielopol (Mondsee, Austria), Dr M. Feist (Montpellier, France) for the charophytes identifications and Dr Y. Bellion (Avignon, France) for informations on the local stratigraphy. Mrs C. Chancogne-Weber (Paris, France) is also sincerely thanked for taking the SEM photographs.

\section{Manuscript received May 1994 Manuscript accepted August 1994}

\section{REFERENCES}

Babinot, J. F. \& Colin, J.-P., 1976. Sarlatina n, gen. (ostracode): sa position dans l'évolution des Cyprideidini Kollmann, 1960. Abhandlungen und Verhandlungen der Naturwissenschaftlichen vereins 
Hamburg, 18/19 (suppl.): 161-174.

Bellion, Y., Lefranc, J.-P. \& Michard, J. G., 1990. Précisions sur l'âge des sédiments méso-cénozoïques à l'ouest de l'Adrar des Iforas (Sahara, Mali, Afrique de l'Ouest). Implications paléogéographiques. $115^{\text {eme }}$ Congrès national des Sociétés savantes, Avignon: 7-27.

Berggren, W. A., 1974. Paleocene benthonic foraminiferal biostratigraphy, biogeography and paleoecology of Libya and Mali. Micropaleontology, 20: 449-465.

Bertels, A. \& Martinez, D. E., 1990. Quaternary ostracodes of continental and transitional littoral-shallow marine environments. Courier Forschungsinstitut Senckenberg, 123: 141-159.

Bhandari, A., 1993. Non-marine ostracoda from the subsurface sequence of the Cambay Shale, Gujarat, India and their paleoecological significance. In McKenzie, K. G. \& Jones, P. J. (Eds), Ostracoda in the Earth and Life Sciences, 673. A. A. Balkema, Rotterdam.

Bhandari, A., Gupta, P. K. \& Juyal, N. P., 1991. Integrated exploration research in Cambay Basin: some aspects of Paleogene stratigraphy. In Pandey, J. \& Barnerjee A. (Eds), Proceedings of the Conference on Integrated Exploration Research, Achievements and Perspectives, 159167.

Carbonnel, G. \& Ritzkowski, S., 1969. Ostracodes lacustres de l'Oligocène (Melanienton) de la Hesse (Allemagne). Archives des Sciences (Genève), 22: 55-82.

Carbonel, P., Colin, J.-P., Danielopol, D.L., Löffler, H. \& Neustrueva, I., 1988. Paleoecology of limnic ostracodes: a review of some major topics. Palaeogeography, Palaeoclimatology, Palaeoecology, 62: 413 461.

Cohen, A.S., Dussinger, R. \& Richardson, J., 1983. Lacustrine paleochemical interpretations based on Eastern and Southern African ostracodes. Palaeogeography, Palaeoclimatology, Palaeoecology, 43: $129-151$.

Colin, J.-P., 1993. An early representative of the genus Frambocythere Colin, 1980: Frambocythere pustulosa (Grékoff, 1957) from the Albian of Zaire. Journal of Micropalaeontology, 12: 170.

Colin, J.-P. \& Danielopol, D. L., 1978. New data on the systematics of the Limnocytheridae (Ostracoda, Cytheracea). Géobios, 11: 563-567.

Colin, J.-P. \& Danielopol, D. L., 1980. Sur la morphologie, la systématique, la biogéographie et l'évolution des ostracodes Timiriaseviinae (Limnocytheridae). Paléobiologie continentale, 11: 1-51.

Colin, J. F., Tambareau, Y. \& Frasheninnikou, V. A. 1996. Ostracodes limniques et lagunaires dans le Cretace Supèrieur du Mali (Afrique de l'Ouest): Systematique, Palèoècologie et affinitës palèobiogèographiques. Revue de Micropalèontologie, 39: 211-222.

Danielopol, D. L., Martens, K. \& Casale, L. M., 1989. Revision on the genus Leucocythere Kaufmann, 1892 (Crustacea, Ostracoda, Limnocytheridae), with the desciption of a new species and two new tribes. Bulletin de l'Institut royal des Sciences naturelles de Belgique, 59: 6394

De Deckker, P., 1981. Taxonomy and ecological notes of some ostracods from Australian Inland waters. Transactions of the Royal Society of South Australia, 105: 91-138.

De Deckker, P., 1982. Non-marine ostracods from two Quaternary profiles at Pulbeena and Mowbray Swamps, Tasmania. Alcheringia, 6: 249-274.

Grékoff, N., 1958. Ostracodes du Bassin du Congo. III. Tertiaire. Annales du Musée royal du Congo Belge, 22: 1-36.

Jones, T. R., 1850. Note on the fossil Cypridae from Nagpur. In Hislop, S. (Ed.) On the Tertiary deposits, associated with Trap-Rock, in the East Indies. Quarterly Journal of the Geological Society of London, 16: 186-189.

Keyser, D., 1977. Ecology and zoogeography of recent brackish-water ostracoda (Crustacea) from south-west Florida. In Löfler, H. \& Danielopol, D. (Eds), Aspects of Ecology and Zoogeography of Recent and Fossil Ostracoda, 207-222, W. Junk, The Hague.

Krasheninnikov, V. A. \& Trofimov, D. M., 1969. Comparative analysis of the benthic foraminifera from Dano-Montian sediments of Mali, Tethyan region and North-West Europe. Voprosy Mikropaleontologii Akademiya Nauk SSSR, 12: 108-144 (in Russian).

Martens, K., 1993. On the taxonomy and zoogeography of the genus Gomphocythere Sars, 1924 (Crustacea, Ostracoda), with the description of a new species from the Nahal Dan (Israel). Belgian Journal of Zoology, 123: 39-54.

Martens, K. \& Beheu, F. 1997. A checklist of the non-marine ostracods (Crustracea, Ostracoda) from South America inland waters and adjacent islands. Travaux scientifiques du Museum d'Histoire Naturelle du Luxembourg, 22: 1-81.

Martin, G. P. R. \& Weiler, W., 1957. Das Aldorfer Otolithen-'Pflaster' und seine Fauna. Senckenbergiana lethaea, 38: 211-250.

McKenzie, K. G., 1971. Palaeozoogeography of freshwater ostracoda. In Oertli, H. J. (Ed.), Paléoécologie des Ostracodes. Bulletin du Centre de Recherches de Pau-SNPA, 5(suppl.): 207-237.

Monostori, M., 1977. Ostracode fauna from the Eocene of Gant (Transdanubian Central Mountains, Hungary). Annales Universitatis Scientarium Budapestinensis, Sectio Geologica, 19: 75-130.

Monostori, M., 1993. The genus Cytheridella in the Palacogene of Eastern Europe. Revista espanola de Micropaleontologia, 25: 107-112.

Pinto, I. D. \& Sanguinetti, Y. T., 1962. A complete revision of the genera Bisulcocypris and Theriosynoecum (Ostracoda) with the world geographical and stratigraphical distribution (including Metacypris, Elpidium, Gomphocythere and Cytheridella). Publicacao especial Escola de Geologia Universidade do Rio Grande do Sul Porto Alegre, 4: 1-165.

Purper, I., 1974. Cytheridella boldii Purper, sp. nov. (Ostracoda) from Venezuela and a revision of the genus $C y$ theridella Daday, 1905. Anais Academia Brasileira de Ciencias, 46: 635-662.

Purper, I., 1977. Some ostracodes from the Upper Amazon Basin, Brazil. Environment and age. In Löffer, H. \& Danielopol, D (Eds), Aspects of Ecology and Zoogeography of Recent and Fossil Ostracoda, 353-367. W. Junk, The Hague.

Purper, I., 1979. Cenozoic ostracodes of the Upper Amazon Basin, Brazil. Pesquisas, 12: 209-281.

Rome, D. R. \& De Deckker, P., 1977. Ostracodes du Lac Kivu. Mémoires de l'Insitut géologique de l'Université de Louvain, 29: 241287.

Schudack, U., 1994. Revision, Dokumentation und Stratigraphie der Ostracoden des nordwestdeutschen Oberjura und Unter-Berriasium. Berliner Geowissenschaften Abhandlungen, E, 11: 1-193.

Sheppard, L. M. \& Bate, R. H., 1980. Plio-Pleistocene ostracods from the upper Amazon of Colombia and Peru. Palaeontology, 23: 97-124.

Tambareau, Y., Feist, M., Gruas-Cavagnetto, C. \& Murru, M., 1989. Caractérisation de l'Ilerdien continental dans le domaine ouestméditerranéen. Comptes rendus de l"Académie des Sciences de Paris: 689-695.

Tambareau, Y., Gruas-Cavagnetto, C., Feist, M. \& Villatte, J., 1991. Flores et faunes continentales ilerdiennes du versant Sud de la Montagne Noire et de la Montagne d'Alaric. Revue de Micropaléontologie, 34: 69-89.

van den Bold, W. A., 1971. Ostracode associations, salinity and depth of deposition in the Neogene of the Caribbean region. In Oertli, H. J. (Ed.), Paléoécologie des Ostracodes. Bulletin du Centre de Recherches de Pau-SNPA, 5 (suppl.): 449-460.

van den Bold, W. A., 1986. Fresh and brackish water ostracoda from the Neogene of northern Venezuela. Tulane Studies in Geology and Paleontology, 19: 141-157

von Daday, E., 1905. Untersuchungen ueber die suesswasser-Mikrofauna Paraguays. Zoologica, 18: 1-374.

Zabert, L. L. \& Herbst, R., 1986. Ostracodos Pleistocenicos del Arroyo Perucho Vernan, Provincia de Entre Rios, Argentina. Ameghiniana, 23: 213-224.

Zalanyi, B., 1913. Miocaene Ostrakoden aus Ungarn. Mitteilungen aus dem Jahrbuch der koeniglichen ungarischen geologischen Reichsanstalt, 21: $83-152$ 